\title{
EVALUASI IPAL KOMUNAL PADA KELURAHAN TLOGOMAS, KECAMATAN LOWOKWARU, KOTA MALANG
}

\author{
EVALUATION OF COMMUNAL WWTP ON TLOGOMAS \\ VILLAGES, LOWOKWARU DISTRICT, MALANG CITY
}

\author{
Edya Pitoyo ${ }^{1}$, Evy Hendriarianti ${ }^{1}$, Nieke Karnaningroem ${ }^{1}$ \\ Teknik Lingkungan, Fakultas Teknik Sipil dan Perencanaan, Institut Teknologi \\ Sepuluh Nopember, Jalan Arif Rahman Hakim Surabaya 60111 \\ Email: edyapitoyo@gmail.com; hendriarianti@yahoo.com; nieke@enviro.its.ac.id
}

\begin{abstract}
Abstrak
Perda Kota Malang nomor 17 tahun 2001 tentang Konservasi Air menyatakan bahwa segala jenis kegiatan yang menimbulkan limbah harus memiliki instalasi pengolahan air limbah (IPAL). Kebijakan tersebut sedang diterapkan oleh pemerintah Kota Malang dengan melakukan pembangunan IPAL Komunal. Pada penelitian ini dilakukan evaluasi terhadap IPAL Komunal yang berlokasi di Kelurahan Tlogomas, Kecamatan Lowokwaru, Kota Malang. Berdasarkan review IPAL Komunal yang dilakukan oleh DEWATS, didapati bahwa mayoritas IPAL Komunal yang dibangun tidak dimonitoring. Untuk itu perlu dilakukan evaluasi terhadap aspek teknis untuk mengetahui kesesuaian perencanaan dengan kriteria desain serta tingkat efektivitas IPAL Komunal. Evaluasi ini dilakukan dengan menggunakan Metoda Comprehensive Performance Evaluation. Evaluasi terhadap aspek lingkungan dari dampak operasional IPAL Komunal dilakukan dengan metoda perbandingan baku mutu. Berdasarkan hasil evaluasi aspek teknis didapatkan efisiensi penyisihan, rasio $\mathrm{BOD} / \mathrm{COD}$, OLR, dan HRT sudah memenuhi kriteria desain. Akan tetapi, terdapat ketidaksesuaian hasil perhitungan rasio BOD/COD, OLR, dan HRT pada perhitungan perencanaan dengan realisasi pembangunan dan pengoperasian. Evaluasi aspek lingkungan mendapati hasil efluen BOD, COD, dan TSS masih belum memenuhi baku mutu yang dipersyaratkan oleh pemerintah Kota Malang.
\end{abstract}

Kata kunci: aspek lingkungan, aspek teknis, evaluasi IPAL komunal.

\begin{abstract}
Malang city's Government Regulation Number 1, 2001, on Water Conservation stated that all kinds of activities that generate waste must have a wastewater treatment plant (WWTP). This policy is being implemented by the government of Malang by constructing communal WWTPs. This study evaluated communal WWTP located in the Tlogomas Village, Lowokwaru District, Malang. DEWATS'review on communal WWTP found that the majority of communal WWTPs built are not monitored. Therefore, it is necessary to evaluate the technical aspects of the design with reference to the design criteria and to confirm it with the existing construction as well as the treatment efficiency. This evaluation was conducted using Comperhensive Performance Evaluation method. Moreover, environmental aspects was also evaluated, by quality standard comparison method, to identify the impact of construction and operation of this facility. Based on the technical aspects evaluation, it was found that removal efficiency, BOD/COD ratio, OLR, and HRT have met the design criteria. Unfortunatly there was calculation inconsistency between planned BOD/COD ratio, OLR, and HRT with the actual ones. As for the environmental aspects evaluation, the results indicate that WWTP-efluent's $B O D, C O D$, and TSS have not met the quality standards required by the government of Malang city.
\end{abstract}

Keywords: communal WWTP evaluation, environmental aspects, technical aspects 


\section{PENDAHULUAN}

Kota Malang dengan luas wilayah $110,10 \mathrm{~km}^{2}$, jumlah penduduk 820.243 jiwa, dan kepadatan penduduk 7.453 jiwa $/ \mathrm{km}^{2}$ terbagi dalam 5 kecamatan dan 57 kelurahan. Kota ini terletak pada koordinat $7.06^{\circ}-8.02^{\circ}$ lintang selatan dan $112.06^{\circ}-112.07^{\circ}$ bujur timur. Kota Malang dengan ketinggian antara 440 - 667 meter dari permukaan laut memiliki letak yang cukup tinggi sehingga memilliki suhu yang cukup sejuk. Tercatat rata-rata suhu udara berkisar antara $23.2{ }^{\circ} \mathrm{C}-24.4{ }^{\circ} \mathrm{C}$ dengan suhu tertinggi adalah $31.4{ }^{\circ} \mathrm{C}$ dan suhu terendah adalah $17.2^{\circ} \mathrm{C}$. Rata-rata kelembapan udara berkisar antara $78 \%$ $-86 \%$ serta memiliki curah hujan tertinggi 526 milimeter. Kota malang ini dilewati oleh sungai Brantas yang memilik panjang $320 \mathrm{~km}$ dengan daerah pengaliran sungai seluas $12.000 \mathrm{~km}^{2}$.

Berdasarkan Perda Kota Malang nomor 17 tahun 2001 tentang Konservasi Air, bahwa segala jenis kegiatan yang menimbulkan limbah harus memiliki instalasi pengolahan air limbah. Kebijakan tersebut sedang diterapkan oleh pemerintah Kota Malang dengan melakukan program PNPM Mandiri yang salah satu kegiatannya adalah mendukung sanitasi yaitu pembangunan IPAL (Instalasi Pengolahan Air Limbah) Komunal.

IPAL Komunal ini dibangun oleh beberapa pihak antara lain Urban Sanitation and Rural Infrastruture (USRI), PKK Kota, Bank dunia, Pinjaman ADB (Asian Develoment Bank), atau Swadaya masyarakat sendiri yang membangun IPAL Komunal untuk mengolah limbah domestik. Warga Kota Malang yang telah membangun fasilitas tempat buang air besar dengan biaya sendiri/mandiri mencapai 76,32\%, sementara $21,45 \%$ menggunakan fasilitas buang air besar bersama dengan keluarga lain, dan sebanyak 1,29\% menggunakan fasilitas umum atau IPAL Komunal.

Hasil analisis kualitas air anak sungai Brantas oleh BLH Kota Malang pada tahun 2011 untuk parameter dissolved oxygen (DO) pada lokasi pembuangan efluen IPAL Mergosono menunjukkan konsentrasi sebesar $2 \mathrm{mg} / \mathrm{L}$ pada bulan Juli; 1,8 mg/L pada bulan Agustus dan 1,85 $\mathrm{mg} / \mathrm{L}$ pada bulan September. Hasil ini menunjukkan rendahnya nilai DO pada sungai penerima efluen IPAL komunal Mergosono. Konsentrasi DO pada lokasi sebelum titik pembuangan efluen di sungai Brantas menunjukkan nilai yang lebih besar yaitu sebesar 2,3 mg/L pada bulan Juli; 2,0 mg/L pada bulan Agustus dan 2,1 mg/L pada bulan September. Rendahnya nilai DO sungai ini salah satunya disebabkan karena kualitas efluen yang masih mengandung bahan organik (BOD dan COD) yang tinggi hingga $92 \mathrm{mg} / \mathrm{L}$ dan $192 \mathrm{mg} / \mathrm{L}$.

Hal ini disinyalir akibat kualitas effluent IPAL Komunal yang belum memenuhi syarat baku mutu air limbah. Oleh karena itu perlu dilakukan evaluasi terhadap kinerja IPAL Komunal yang dibangun di Kota Malang.

Pembuangan efluen IPAL Komunal pada sungai sebagai badan air penerima harus sesuai dengan baku mutu efluen dan baku mutu sungai penerima. Penetapan nilai baku mutu efluen Iimbah dan baku mutu sungai di Indonesia masih menggunakan pendekatan normatif. Pendekatan baku mutu sungai secara nomatif ini masih belum menggambarkan kondisi sungai sebagai badan air penerima efluen.

Sementara itu, dalam desain sistem pengolahan limbah domestik secara komunal masih belum ada kajian kriteria desain yang sesuai dengan karakteristik kuantitas dan kualitas limbah domestik di Indonesia. Hasil studi komparasi IPAL terpusat di Indonesia melalui Environment Service Program dari USAID (United States Agency for International Development) pada tahun 2010 menunjukkan semua IPAL terpusat yang dikaji memiliki beban pengolahan rendah.

Pada penelitian ini dilakukan pengambilan sampel dari IPAL Komunal di Kota Malang yang terletak di Kelurahan Tlogomas Kecamatan Sukun yang menggunakan teknologi Anaerobic Baffled Reactor (ABR). ABR ini telah banyak diaplikasikan dalam mengolah limbah domestik skala komunal sesuai dengan berbagai pertimbangan aspek kelayakan teknik, sosial, dan lingkungan. ABR memiliki biaya desain 
yang sederhana, modal yang rendah, dan biaya operasi yang murah (Bachman et al., 1985 dan Garuti et al., 2001).

Akhir-akhir ini beberapa sistem reaktor telah diujicobakan untuk mengolah berbagai macam air limbah domestik. Sistem pengolahan secara anaerobik dipilih dikarenakan memiliki keunggulan jika dibandingkan dengan pengolahan secara aerobik dikarenakan lebih murah, mudah dioperasikan dan dapat menciptakan energi berupa gas metana (Bodkhe, 2009). Salah satu yang cukup popular utuk mengolah air limbah domestik adalah penggunaan Upflow Anaerobik Sludge Blanket (UASB) terutama di negara berkembang yang memiliki iklim tropis dan subtropis. McCarty kemudian memodifikasi UASB ini menjadi ABR yang lebih mudah dioperasikan. Studi kelayakan penggunaan ABR untuk mengolah air limbah domestic secara on-site sudah sering didiskusikan (Sarathai, 2010). Beberapa publikasi telah menunjukkan bahwa ABR berpotensi untuk efektif untuk mengolah air limbah (Manariotis and Grigoropoulos, 2002) (Wang, et al., 2004). ABR ini adalah serangkaian reaktor yang bersekat, yang memungkinkan air untuk naik dan turun mengikuti aliran air dan bakteri yang terdapat pada reaktor akan mengolah dan memakan bahan organik di dalam air limbah dan menghasilkan gas metana. Keunggulan utama ABR adalah kemapuannya untuk memisahkan proses asidogenesis dan metanogenesis secara longitudinal sehingga reaktor dapat bertindak seperti dua reaktor yang memiliki fase terpisah namun terintegrasi tanpa memerlukan control tenaga manusia dan biaya tambahan (Barber and Stuckey,1991).

Pengolahan anaerobik untuk air limbah domestik yang memiliki kandungan bahan organik dan dapat menghasilkan metan sangat cocok digunakan pada daerah tropis dan subtropis seperti di Amerika, Afrika, Timur Tengah, Asia di mana efisiensi penyisihan dari COD berkisar antar 40 sampai dengan $75 \%$. Penggunaan ABR ini tidak biasa digunakan pada daerah dengan suhu yang sedang $\left(12-23^{\circ} \mathrm{C}\right)$.
ABR ini adalah serangkaian reaktor Upflow Anaerobic Sludge Blanket (UASB), air limbah dialirkan secara berurutan dalam kondisi upflow dan downflow setiap kali melewati sludge blanket (Grobicki and Stuckey, 1991). Konfigurasi tersebut membantu pemisahan secara spasial mikroorganisme yang sedang melakukan tahap hidrolisis, asidogenesis, dan metanogenesis. ABR mampu mengolah air limbah dengan kandungan TSS tinggi tanpa mengalami pembuntuan dan mapu meproduksi biogas yang semakin murni dan bagus konsentrasinya pada akhir reaktor (Hanh, 2015).

Salah satu lembaga yang menggunakan IPAL Komunal dengan system ABR ini adalah DEWATS yang sudah menerapkannya di Indonesia, Filipina, Kamboja, Vietnam, dan Laos. Berdasarkan laporan review IPAL Komunal yang disusun oleh Eales pada 2013, $20 \%$ IPAL komunal tidak beroperasi lagi dan $80 \%$ sisanya beroperasi dengan kualitas efluent yang tidak dimonitoring oleh masyarakat. Hal ini disebabkan karena keterbatasan kemampuan.

Menurut Laporan Rencana Induk Air Limbah Kota Malang tahun 2011, kinerja salah satu IPAL Komunal yang telah terbangun yaitu IPAL Mergosono kota Malang dengan kapasitas 6000 jiwa memiliki Efisiensi penyisihan TSS, BOD dan COD pada tahun 2011 sebesar 17,81\%, $26,98 \%$ dan $27,27 \%$. Oleh sebab itu perlu dilakukan evaluasi terhadap aspek teknis (rasio BOD/COD, OLR, HRT, dan efisiensi penyisihan) untuk mengevaluasi hasil pengoperasian dan pengolahan IPAL Komunal. Selain itu, pada laporan review IPAL Komunal tidak ada laporan mengenai dampak lingkungan yang diakibatkan selama masa pembangunan dan masa operasi sehingga perlu dilakukan evaluasi terhadap aspek lingkungan dari pembangunan IPAL Komunal tersebut.

Diharapkan dengan terbangunnya IPAL tersebut, pembuangan efluen IPAL Komunal ke sungai sebagai badan air penerima sesuai dengan baku mutu efluen dan baku mutu sungai penerima. Hal inilah yang mendasari dilakukannya evaluasi terhadap IPAL Komunal 
di Kota Malang yang berpengaruh terhadap kualitas sungai Brantas.

\section{METODA}

\section{Lokasi Penelitian}

Lokasi yang dijadikan tempat penelitian untuk evaluasi IPAL Komunal di Kota Malang ind. adalah IPAL Komunal di Kecamatan Sukun, Kelurahan Tlogomas. Lokasi tersebut dipilih karena IPAL yang berada pada lokasi tersebut efluen air limbahnya langsung disalurkan ke . badan air sungai Brantas.

\section{Langkah Kerja Penelitian}

Proses langkah kerja penelitian ini meliputi survey lokasi awal, kemudian pengambilan data dan sampel. Survey lokasi awal adalah untuk melihat kondisi pengoperasian IPAL apakah masih beroperasi atau sudah tidak beroperasi dan untuk mendapatkan karakteristik warga pengguna IPAL Komunal dengan melakukan interview dan memberikan pertanyaan yang disusun dalam kuesioner. Data IPAL Komunal dapat berupa data primer dan data sekunder. Data dan sampel tersebut kemudian dianalisis dan dievaluasi berdasarkan aspek teknis dan lingkungan

\section{Metode Pengumpulan Data}

Pengambilan sampel air limbah dilakukan pada influen dan efluen IPAL Komunal. Pengambilan sampel dilakukan pada saat jam puncak (antara pukul 05.00 - 06.00 pagi atau pukul 16.00 17.00 sore) dengan menggunakan metode grab sample (sampel sesaat). Selanjutnya dilakukan pengujian laboratorium untuk parameter BOD, COD, TSS, $\mathrm{NO}_{3}$, dan $\mathrm{PO}_{4}$. Pengukuran debit air limbah eksisting dilakukan dengan menggunakan flowmeter atau gelas ukur dan stopwatch.

\section{Tahap Pengumpulan Data}

Data - data yang dikumpulkan dalam penelitian ini dibagi menjadi 2 bagian, yaitu data untuk aspek teknis dan data aspek lingkungan. Detail data yang diperlukan dalam evaluasi ini untuk tiap bagian adalah sebagai berikut :

Aspek Teknis

1. Data desain operasi dan proses dan data pengguna IPAL dari dinas kebersihan dan pertamanan kota Malang.

Pengukuran aliran influen dan efluen di setiap unit pengolahan IPAL Komunal dengan flowmeter atau menggunakan gelas ukur dan stopwatch.

4. Sampling dan analisa parameter kualitas influen dan efluen di setiap unit pengolahan IPAL komunal yang meliputi konsentrasi BOD, COD, TSS, $\mathrm{NO}_{3}, \mathrm{PO}_{4}$. Sampling air limbah dilakukan dengan metode grab sample (sampel sesaat) pada saat jam puncak (pagi pada pukul 05.00 - 06.00 dan sore pada pukul $16.00-17.00$ ) sesuai dengan SNI 6989.57:2008.

\section{Aspek Lingkungan}

Membandingkan hasil efluen IPAL Komunal dengan Baku Mutu Peraturan Gubernur Jawa Timur No. 72 tahun 2013.

\section{Tahap Pengolahan dan Analisis Data}

Data-data yang berhasil dikumpulkan dalam penelitian ini kemudian di evaluasi berdasarkan, aspek teknis dan aspek lingkungan. Detail pengolahan dan analisis data adalah sebagai berikut:

\section{Aspek Teknis}

1) Membandingkan disain kriteria (OLR dan HRT) berdasarkan studi literatur dan pedoman perencanaan air limbah komunal.

2) Melakukan perhitungan OLR dengan persamaan

3) Melakukan perhitungan HRT dengan persamaan

$$
\mathrm{HRT}=\frac{\text { Volume of ABR }}{\mathrm{Q}}
$$

4) Membandingkan Efisiensi pengolahan dan kualitas efluen dari kapasitas desain reaktor 
unit pengolahan berdasarkan penelitian terdahulu.

5) Melakukan perhitungan efisiensi penyisihan (ER) dengan persamaan

$$
\mathrm{ER}=\frac{\text { Influen - efluen }}{\text { influen }} \times 100 \%
$$

6) Melakukan perhitungan rasio BOD/COD dengan persamaan

$$
\text { Rasio }=\frac{\mathrm{BOD}}{\mathrm{COD}}
$$

\section{Aspek Lingkungan}

Mengevaluasi dampak yang dihasilkan apabila hasil efluen tidak memenuhi baku mutu yang dipersyaratkan yaitu Peraturan Gubernur Jawa Timur Nomor 72 tahun 2013 dan membandingkan dengan studi literatur dampak yang diakibatkannya.

\section{HASIL DAN PEMBAHASAN}

\section{Karakteristik Warga Pengguna IPAL}

Karakteristik warga pengguna IPAL Tlogomas untuk jenis pekerjaan didominasi oleh pekerja swasta dan buruh, dengan tingkat pendidikan mayoritas pengguna adalah tamatan SMP dan SD.

Tingkat pendapatan warga pengguna IPAL di Tlogomas mayoritas sebesar 1.000 .000 rupiah sampai dengan 1.500.000 rupiah dengan tingkat pengeluaran 500.000 rupiah sampai dengan 1.000.000 rupiah. Sumber air bersih warga pengguna IPAL Tlogomas seluruhnya didapatkan dari air sumur dan sumber air minum warga mayoritas juga menggunakan air sumur.

Warga pengguna IPAL Tlogomas mayoritas mengaku sudah dilakukan sosialisasi terkait pembangunan dan pengoperasian IPAL Komunal tetapi dari hasil sosialisasi tersebut hanya sebagian kecil saja warga yang paham mengenai sanitasi dan IPAL Komunal.

Berdasarkan hasil interview warga pengguna IPAL Komunal Tlogomas membayar retribusi pengolahan air limbah sebesar 3000 rupiah setiap bulannya. Uang retribusi itu diserahkan kepada pengelola IPAL Komunal yang bertanggung jawab untuk masalah administrasi keuangan.

Pada penelitian yang dilakukan Yudo dan Indriatmoko (2006), yaitu mengevaluasi hasil pembangunan instalasi pengolah air limbah domestik tipe komunal di wilayah Kotamadya Jakarta Pusat. Berdasarkan hasil penelitian warga masyarakat yang diinterview sebagian besar warga pengguna IPAL memiliki pekerjaan tidak tetap kemudian sebagai pedagang,dan buruh. IPAL komunal hanya dikelola oleh 1 atau 2 orang saja dari warga yang ditunjuk langsung oleh pengurus RT/RW, dan biaya retribusi sebesar 500 rupiah sampai dengan 1000 rupiah. Sebagian besar warga pengguna IPAL paham bahwa membuang limbah langsung ke sungai dapat mencemari lingkungan.

Warga pengguna IPAL Komunal pada penelitian ini dan pada penelitian yang dilakukan oleh Yudo dan Indriatmoko (2006) memiliki kesamaan pada karakteristik warga pengguna IPAL. Hal ini disebakan pengguna IPAL Komunal secara umum adalah orang dengan tingkat pendapatan rendah dan tingkat pendidikan yang juga rendah. Keberadaan IPAL Komunal bagi warga masyrakat ini sangat berguna dikarenakan sebagian besar warga masih belum memiliki WC ataupun septic tank yang memadai sesuai dengan peraturan pemerintah yang diatur dalam Standar Nasional Indonesia (SNI) nomor 03-2389-2002 tentang Tata Cara Perencanaan Tangki Septik dengan Sistem Resapan.

\section{Analisis Aspek Teknis}

IPAL Tlogomas ini memiliki ukuran panjang 0.8 $\mathrm{m}$, lebar $2.37 \mathrm{~m}$, tinggi $2 \mathrm{~m}$, dan waktu tinggal 15 jam. IPAL Tlogomas in memiliki tingkat pelayanan sebanyak $137 \%$ berdasarkan data yang didapatkan, IPAL ini melayani 96 kepala keluarga yang memiliki 480 jiwa tetapi, IPAL Komunal ini didesain untuk melayani 350 jiwa. IPAL Komunal Tlogomas ini termasuk IPAL Komunal yang over capacity atau melebihi kapasitas perencanaan pengguna. Perhitungan rasio BOD/COD dimaksudkan untuk mengetahui tingkat biodegradable limbah, pada IPAL Komunal ini rasio BOD/COD adalah 0,56 pada 
influent dan 0,57 pada efluen,hal ini berarti mengindikasikan air limbah yang dihasilkan dapat di olah menggunakan pengolahan biologis dikarenakan rasio BOD/COD air limbah yang dapat diolah secara biologis berkisar antara 0,3 sampai dengan 0,8 (Tchobanoglous et al., 2004).

Evaluasi kapasitas unit pengolahan dilakukan untuk mengetahui kapasitas bangunan pengolahan eksisting terhadap kapasitas rencana. Debit rencana untuk IPAL Komunal Tlogomas ini adalah 45,79 $\mathrm{m} 3 /$ hari dan debit eksisting yang didapatkan dari pengukuran influent adalah 42,33 m3/hari. Debit yang didapatkan dari hasil pengukuran menunjukkan bahwa air limbah yang masuk lebih kecil dari perencanaan, perbedaan debit rencana dan eksisting ini akan berpengaruh terhadap OLR dan HRT yang nantinya akan mementukan besarnya efisiensi penyisihan pada IPAL Komunal di Tlogomas ini.

Pada IPAL Komunal ini menggunakan teknologi Anaerobic baffled Reactor, dilakukan pemgambilan sampel pada inlet maupun outlet IPAL untuk mendapatkan kandungan konsentrasi BOD, COD, dan TSS sehingga bisa diketahui efisiensi penyisihan dari IPAL Komunal Tlogomas. Hasil pengukuran BOD, COD, TSS dan efisiensi penyisihan nya dapat dilihat pada Tabel 1 berikut

Tabel 1. Efisiensi Penyisihan dan Hasil Pengukuran

\begin{tabular}{lllll}
\hline Parameter & $\begin{array}{l}\text { Influen } \\
(\mathrm{mg} / \mathrm{L})\end{array}$ & $\begin{array}{l}\text { Effluen } \\
(\mathrm{mg} / \mathrm{L})\end{array}$ & $\begin{array}{l}\text { Baku } \\
\text { Mutu } \\
(\mathrm{mg} / \mathrm{L})\end{array}$ & $\begin{array}{l}\text { Efisiensi } \\
\text { Penyisihan } \\
(\%)\end{array}$
\end{tabular}

\begin{tabular}{lllll}
\hline COD & 224 & 64 & 50 & 71.43 \\
\hline BOD & 128 & 36 & 30 & 71.88 \\
\hline TSS & 170 & 26 & 50 & 84.71 \\
\hline
\end{tabular}

Sumber : Hasil Analisa (2015)

Pada evaluasi IPAL Komunal ini didaptkan hasil efisiensi penyisihan untuk konsentrasi COD sebesar 71,43\%, konsentrasi BOD sebesar $71,88 \%$, dan konsentrasi TSS sebesar $84,71 \%$. Berdasarkan kriteria desain oleh Sasse (1998), efisiensi penyisihan ABR untuk konsentrasi BOD antara $70 \%$ - $95 \%$ dan penyisihan konsentrasi COD antara 65\% - 90\%.
Pada penelitian yang dilakukan Wulandari (2015) yaitu melakukan evaluasi 3 IPAL Komunal di Kecamatan Pankkukang Kota Makassar didapatkan hasil efisiensi penyisihan untuk TSS berkisar antara 72,48\% sampai dengan $99,7 \%$, pada parameter BOD efisiensi penyisihan yang didapatkan berkisar antara $51,39 \%$ sampai dengan $73,17 \%$., Pada parameter COD didapatkan efisiensi penyisihan antara $16,92 \%$ sampai dengan 33,25\%. Efisiensi penyisihan yang kecil dikarenakan pemeliharaan IPAL yang kurang baik dan adanya sumbatan pada bak screening pada IPAL Komunal di Makkasar.

Pada IPAL Komunal di Tlogomas ini pemeliharaan IPAL sudah dilakukan dengan baik karena karena ada SOP pemeliharaan dan warga bersedia membayar retribusi untuk pemeliharaan sehingga efisiensi penyisihan oleh IPAL Komunal Tlogomas ini masih memenuhi kriteria desain yang diharapkan yaitu kriteria desain oleh Sasse.

Pada penelitian yang dilakukan oleh Hahn (2015), ABR berukuran $0.457 \mathrm{~m}^{2}$, tinggi $1.22 \mathrm{~m}$ dan memiliki reaktor sebanyak 4 reaktor dengan volume hidrolik sebesar $869 \mathrm{~L}$, dioperasikan selama 2 tahun dengan kondisi lingkungan 12 $23^{0} \mathrm{C}$, dengan waktu tinggal hidrolis $12 \mathrm{jam}$, rata - rata influen TSS adalah $510 \mathrm{mg} / \mathrm{l}$ dan BOD 320 $\mathrm{mg} / \mathrm{L}$ dan COD $760 \mathrm{mg} / \mathrm{L}$, didapatkan efisisensi pengolahan sebesar $83 \%$ untuk TSS, $47 \%$ untuk BOD dan $43 \%$ untuk COD. Efisiensi penurunan untuk BOD dan COD yang didapatkan rendah karena suhu yang lebih rendah dari $20^{\circ} \mathrm{C}$ mempengaruhi hasil pengolahan. Penelitian yang dilakukan Hahn ini dilakukan dengan kondisi iklim yang sama sesuai dengan kondisi iklim Kota Malang yaitu memiliki suhu antara $17^{\circ} \mathrm{C}$ sampai dengan $31^{0}$ C. pada evaluasi IPAL Komunal di Tlogomas ini efisiensi penyisihan yang didapatkan masih memenuhi kriteria desain oleh Sasse dikarenakan suhu pengolahan pada siang hari yang mencapai $31^{\circ} \mathrm{C}$ terjadi lebih lama dibandingkan suhu dibawah $20^{\circ} \mathrm{C}$ yang dapat mempengaruhi pengolahan oleh ABR.

Efisiensi penyisihan yang baik selain memperhatikan suhu pengolahan juga 
disebabkan oleh beban organik yang diolah atau nilai OLR dan juga lamanya waktu tinggal air atau HRT.

Perbandingan Organic Loading Rate rencana dengan eksisting dilakukan untuk mengevaluasi kandungan organik sebagai bahan makanan mikroorganisme. Jika organik loading rate terlalu kecil atau terlalu besar dapat mengakibatkan kurang baiknya proses yang terjadi didalam reaktor anaerobic baffled reactor. Perbandingan Perbandingan Rencana dan Eksisting IPAL Tlogomas dapat dilihat pada Tabel 2 berikut

Tabel 2. Perbandingan Rencana dan Eksisting IPAL Tlogomas

\begin{tabular}{llrr}
\hline Parameter & Unit & \multicolumn{1}{c}{ Rencana } & \multicolumn{1}{c}{ Eksisting } \\
\hline $\mathrm{Q}$ & $\mathrm{m}^{3} /$ hari & 42.33 & 45.79 \\
\hline BOD & $\mathrm{kg} / \mathrm{m}^{3}$ & 0.35 & 0.12 \\
\hline Vol & $\mathrm{m}^{3}$ & 18.96 & 18.96 \\
\hline OLR & $\begin{array}{l}\mathrm{kg} \mathrm{BOD} / \\
\mathrm{m}^{3} \text { hari }\end{array}$ & 0.85 & 0.29 \\
\hline HRT & jam & 9.84 & 10.80 \\
\hline
\end{tabular}

Sumber : Hasil Analisa (2015)

Pada pengolahan biologis, Hidraulic Retention Time (HRT) sangat berpengaruh terhadap efisiensi pengolahan air limbah karena untuk menguraikan zat organik yang terkandung didalam air limbah mikroorganisme memerlukan waktu kontak yang cukup.

Pada evaluasi IPAL Komunal di Tlogomas ini didaptkan OLR $0,29 \mathrm{~kg} \mathrm{BOD} / \mathrm{m}^{3}$ hari dengan HRT selama 10,8 jam. OLR ini memenuhi kriteria desain oleh Tchobanoglous yaitu kurang dari $<6 \mathrm{~kg} \mathrm{BOD} / \mathrm{m}^{3}$ tetapi tidak sesuai dengan kriteria desain oleh Sasse yaitu antara 4-5 kg $\mathrm{BOD} / \mathrm{m}^{3}$. OLR yang kecil ini dapat berakibat pada efisiensi penyisihan yang tidak sesuai rentang kriteria desain. Sementara untuk HRT tela memenuhi kriteria desain yaitu $>8$ jam. HRT yang lebih lama akan membuat efisiensi penyisihan menjadi lebih tinggi karena waktu kontak antara mikroorganisme dengan air limbah untuk menguraikannya menjadi lebih lama. OLR yang kecil dapat pula diatasi dengan meningkatkan HRT pada pengolahan atau menurunkan debit pengolahan sehingga air limbah memiliki waktu kontak yang lebih lama dengan mikroorganisme yang akan menguraikan bahan pencemar pada air limbah.

Pada penelitian yang dilakukan Krishna (2009), ABR dioperasikan untuk mengolah air limbah konsentrasi rendah yang kompleks dengan konsentrasi COD $500 \mathrm{mg} / \mathrm{L}$ dengan HRT 20 jam (OLR $=0,6 \mathrm{~kg} \mathrm{COD} / \mathrm{m} 3$ hari $)$, pada saat awal efisiensi penyisihan mencapai $50-60 \%$ dan dalam 50 hari pengoperasian meningkat menjadi $70-80 \%$. Pada HRT 16 dan 12 didapatkan efisiensi penyisihan sebesar $80 \%$. Hasil terbaik pengolahan ABR didapatkan ketika HRT yang digunakan adalah 8 dan 10 jam $($ OLR $=1,2$ dan $1,5 \mathrm{~kg} \mathrm{COD} / \mathrm{m} 3$ hari) dengan tingkat efisiensi penyisihan sebesar $90 \%$.

Pada penelitian oleh Krishna efisiensi penyisihan semakin baik meskipun HRT diturunkan, tetapi OLR dinaikkan. Pada saat awal efisiensi penyisihan yang didaptkan hanya sebesar $50 \%$ $60 \%$ dikarenakan mikroorganisme dalam reaktor masih menyesuaikan diri. Hasil terbaik pada penelitian tersebut didapatkan ketika HRT 8 dan 10 jam karena air limbah komples yang diolah dinaikkan OLR nya dari $0,6 \mathrm{~kg} \mathrm{COD} / \mathrm{m}^{3}$ hari menjadi $1,5 \mathrm{~kg} \mathrm{COD} / \mathrm{m}^{3}$ hari.

Hal ini menunjukkan bahwa jika OLR tinggi maka HRT yang sebentar tidak akan mempengaruhi kinerja ABR hal ini terbukti dari efisiensi penyisihan yang dapat mencapai $90 \%$. Jika OLR yang diolah kecil maka HRT perlu dibuat lebih lama agar efisiensi penyisihan yang didaptkan sesuai dengan perencanaan.

Pada penelitian lain yang dilakukan oleh Krishna (2009) ABR dioperasikan untuk mengolah air limbah konsentrasi rendah yang larut dengan konsentrasi COD $500 \mathrm{mg} / \mathrm{L}$. pada HRT 8 jam hasil efluen ang didapat menunjukkan konsentrasi $50 \mathrm{mg} / \mathrm{L}$ dan pada HRT 10 jam hasil efluen yang didapat menunjukkan konsentrasi 37 $\mathrm{mg} / \mathrm{L}$. hal ini bebrarti ABR yang di operasikan mampu mengolah air limbah hingga mencapai efisiensi penyisihan antara $90 \%-92,6 \%$.

Pada penelitian tersebut dengan OLR yang sama dan divariasikan HRT nya didapatkan bahwa semakin lama HRT maka pengolahan menjadi 
semakin baik hal ini terlihat berdasarkan efisiensi penyisihan yang tercatat.

Pada penelitian lain yang dilakukan oleh Thanwised (2012), pada OLR 16,15 g COD/L hari dengan HRT 24 jam didapatkan efisiensi penyisihan sebesar 14,02 \%, pada OLR 22,50 g COD/L hari dengan HRT 18 jam didapatkan penyisihan sebesar 19,28 \%, pada OLR 31,84 dengan HRT 12 jam didapatkan penyisihan sebesar 25,24\%, pada OLR 65,92 g COD/L hari dengan HRT 6 jam didapatkan penyisihan sebesar 29,30\% dan pada OLR 130,82 g COD/L hari dengan HRT 3 jam didapatkan penyisihan sebesar 21,97\%. Ketika HRT diturunkan dan OLR dinaikkan akan menambah jumlah substrat yang diumpankan kepada sistem ABR sehingga meningkatkan efisiensi penyisihan dari system ABR tersebut. Efisiensi penyisihan terbesar didapatkan ketika HRT 6 jam.

Pada penelitian lain yang dilakukan Ahamed (2015) ABR dioperasikan untuk mengolah air limbah sampah makanan dengan OLR 0,5 - 1,0 g COD/L hari dengan HRT selama 30 hari didapatkan efisiensi penyisihan sebesar $94,5 \%$ hal ini sesuai dengan penelitian yang dilakukan oleh Bachmann et al. (1985).

Pada penelitian oleh Thanwised OLR yang dibebankan melebihi kriteria desain yang ditetapkan meskipun HRT yang digunakan sesuai dengan HRT dari kriteria desain hal ini berakibat pada efisiensi penyisihan yang didapatkan menjadi rendah. Efisiensi penyisihan yang rendah dikarenakan mikrorganisme tidak memiliki cukup waktu untuk menguraikan substrat yang ada pada air limbah. Pada penelitian oleh Ahamed HRT yang digunakan mencapai 30 hari lebih besar 30 kali lipat dari HRT minimal sehingga meskipun OLR hanya sebesar 0,5 g COD/L hari efisiensi penyisihan yang didapatkan masih mencapai $94,5 \%$.

Menurut penelitian yang dilakukan Tawfik et al., (2011) efisiensi penyisihan yang tinggi bisa didapatkan dengan memperpendek HRT tetapi hal ini tidak berlaku untuk air limbah dengan konsentrasi TSS yang tinggi seperti air limbah sampah makanan.

\section{Analisis Aspek Lingkungan}

Berdasarkan hasil pengujian terhadap air limbah hasil olahan pada IPAL yang berlokasi di Tlogomas ini kemudian dibandingkan dengan baku mutu air limbah yang dipersyaratkan sesuai Peraturan Gubernur Jawa Timur Nomor 72 Tahun 2013 tentang Baku Mutu Air Limbah Bagi Industri dan/atau Kegiatan Usaha Lainnya, untuk mengetahui proses pengolahan yang terjadi akan menimbulkan dampak terhadap lingkungan atau tidak.

Pada penelitian yang dilakukan Wulandari (2015) yaitu melakukan evaluasi 3 IPAL Komunal di Kecamatan Panakukang Kota Makassar didapatkan hasil pengolahan air limbah meski memiliki efisiensi penyisihan yang besar tetapi masih belum bisa memenuhi baku mutu yang dipersyaratkan untuk parameter TSS dan BOD. Hasil efluen untuk parameter COD sudah dibawah baku mutu yang dipersyaratkan meskipun untuk efisiensi penyisihan masih dibawah kriteria desain. Hasil efluen yang belum memenuhi baku mutu dan efisiensi penyisihan yang tidak sesuai dengan kriteria desain pada penelitian tersebut disebakan oleh buruknya pemeliharaan dan perhatian yang diberikan pengelola terhadap IPAL Komunal yang telah dibangun dan dioperasikan tersebut.

Pada penelitian yang dilakukan Feng et al. (2009) dilakukan pengolahan air limbah domestic dengan HRT tetap yaitu 18 jam dan variasi konsentrasi antara 300, 450, dan $600 \mathrm{mg} / \mathrm{L}$ dan suhu antara $10-28{ }^{\circ} \mathrm{C}$. penelitian tersebut menghasilkan kesimpulan bahwa hasil effluent masih memenuhi baku mutu yang dipersyaratkan di China yaitu dibawah $100 \mathrm{mg} / \mathrm{L}$. Penurunan temperature dari 35 ke $25{ }^{\circ} \mathrm{C}$ tidak mempengaruhi performa dari $\mathrm{ABR}$ tetapi penurunan suhu dibawah $15{ }^{\circ} \mathrm{C}$ akan mempengaruhi kinerja ABR

Berdasarkan hasil pengujian kualitas air limbah hasil olahan dan dibandingkan dengan baku mutu air limbah yang diperbolehkan diketahui bahwa untuk parameter TSS sudah memenuhi baku mutu yang dipersyaratkan. Hasil efluen TSS dari IPAL Komunal tersebut jika 
dibandingkan dengan kriteria perairan oleh Canter dan Hill dengan kandungan TSS sebesar $26 \mathrm{mg} / \mathrm{L}$ termasuk kriteria perairan yang sangat buruk dan sedikit berbahaya untuk biota perairan.

Kandungan zat tersuspensi yang berlebihan dapat menyebabkan terhalangnya sinar matahari untuk proses fotosintesis sehingga menyebabkan kurangnya oksigen terlarut didalam badan air. Kandungan zat padat tersuspensi yang dikeluarkan oleh IPAL Komunal ini masih dibawah bakumutu yang dipersyaratkan sehingga energi matahari yang dilepaskan masih dapat digunakan untuk proses fotosintesis.

Berdasarkan hasil pengujian kualitas air limbah hasil olahan dan dibandingkan dengan baku mutu air limbah yang diperbolehkan untuk dibuang ke badan air diketahui bahwa untuk kandungan BOD dan COD pada IPAL Komunal Tlogomas, hasil efluen IPAL masih belum memenuhi baku mutu yang dipersyaratkan.

Hal ini dapat menyebabkan pencemaran pada badan air sungai yaitu tingginya kandungan bahan organik yang dapat menyebabkan berkurangnya kadar oksigen di air akibat dari penguraian dan dekomposisi material organik oleh bakteri aerob sehingga oksigen yang terlarut di air akan habis dan mengakibatkan air sungai tidak dapat melakukan self purification dan hanya beberapa spesies saja yang dapat hidup pada air sungai tersebut.

Bahan kimia organik yang mencemari sungai dapat pula berpengaruh terhadap manusia dan juga hewan terutama ikan dan organism air lainnya. Air sungai yang tercemar bahan organik dan dikonsumsi dapat menyebabkan gangguan pada ginjal gangguan kelahiran, dan beberapa macam bentuk kanker pada hewan percobaan di laboratorium.

\section{KESIMPULAN}

Berdasarkan hasil evaluasi pada pengelolaan IPAL Komunal di Kota Malang dapat ditarik kesimpulan sebagai berikut
Evaluasi aspek teknis untuk efisiensi penyisihan BOD dan COD IPAL sudah memenuhi kriteria, rasio BOD/COD IPAL memenuhi kriteria untuk dilakukan pengolahan biologis karena memenuhi rentang antara $0,3-0,8$ yaitu adalah 0,56 pada influen dan 0,57 pada efluen, OLR IPAL Komunal memenuhi kriteria desain yaitu $<6 \mathrm{~kg}$ $\mathrm{BOD} / \mathrm{m}^{3}$ hari meskipun berbeda dengan OLR rencana, HRT IPAL memenuhi kriteria desain yang dianjurkan yaitu $>8$ jam tetapi melebihi HRT perencanaan. Untuk evaluasi aspek lingkungan pada IPAL Komunal Tlogomas, hasil efluen BOD dan COD belum memenuhi baku mutu sementara hasil efluen TSS masih sudah memenuhi baku mutu.

\section{DAFTAR PUSTAKA}

Ahamed, A., Chen, C.L., Rajagopal, R., Wu, D., Mao, Y., Ho, I.J.R. Lim, J.W., Wang, J.Y. 2015. Multi-phased Anaerobic Baffled Reactor Treating Food Waste. Bioresource Technology. 182. pp 239-244.

Bachman, A., Beard, V., McCarty, P. 1985. Performance Characteristics of the Anaerobic Baffled Reactor. Water Res. 19(1). pp 99-106.

Barber, W.P., Stuckey, D.C. 1999. The Use of The Anaerobic Baffled Reactor (ABR) for Wastewater Treatment : A Review. Water Res. 33(7). pp 1559-1578.

Bodkhe, S.Y. 2009. A Modified Anaerobic Baffled Reactor for Municipal Wastewater Treatment. Journal of Environmental Management. 90(8). pp 2488-2493.

Feng, H.J., Hu, L.F., Shan, D., Fang, C.R., Shen, D.S. 2008 Effect of Temperature and Hydraulic Retention Time (HRT) on Treatment of Dilte Wastewater in a Carrier Anaerobic Baffled Reactor. Biomedical and Environmental Sciences. 21(6). pp 460-466.

Garuti, G., Giordano, A., Pirozzi, A. 2001. Full Scale ANANOX System Performance. Water SA. 27(2). pp 189-198. 
Grobicki, A., Stuckey, D.C. 1991. Performance of the Anaerobic Baffled Reactor Under Steady State and Shock Loading Conditions. Biotechnol.37(4). pp 344-355.

Hahn, M.J., Figueroa, L.A. 2015. Pilot Scale Application for Biologically Enhanced Primary Treatment of Raw Municipal Wastewater. Water Res. 87. pp 494-502.

Krishna, G.V.T.G., Kumar, P., Kumar, P. 2008. Treatment of Low Strenght Complex Wastewater Using an Anaerobic Baffled Reactor (ABR). Bioresource Technology. 99(17). pp 8193-8200

Krishna, G.V.T.G., Kumar, P., Kumar, P. 2009. Treatment of Low Strength Soluble Wastewater Using an Anaerobic Baffled Reactor (ABR). Journal of Environmental Management. 90(1). pp 166-176.

Manariotis, I.D., Grigoropoulos, S.G. 2002. Low Strength Watewater Treatment Using an Anaerobic Baffled Reactor. Water Environmental Research. 74(2). pp 170176.

Sarathai, Y., Kootatep, T., Morel, A. 2010. Hydraulic Characteristic of an Anaerobic Baffled Reactor as Onsite Wastewater Treatment System. Journal of Environmental Science. 22(9). pp 13191326.

Sasse, L. 1998. Decentralized Waste Water Treatment in Developing Countries. DEWATS. Borda.
Tawfik, A., Salem, A., El-Qelish, M. 2011. Two tage Anaerobic Baffled Reactors for BioHydrogen Production from Municipal Food Waste. Bioresource Technology. 102(18). pp 8723-8726.

Thanwised, P., Wirojanagud, W., Reungsang, A. 2012. Effect f Retention Time on Hydrogen Production and Chemical Oxygen Demand Penyisihan from Tapioca Wastewater using Anaerobic Mixed Cultures in Anaerobic Baffled Reactor (ABR). International Journal of Hydrogen Energy. 37(20). pp 15503-15510.

Tchobanoglous, G., Burton, F. L., Stensel, H. D. 2004. Wastewater Engineering: Treatment and Reuse, $4^{\text {th }}$. Metcalf and Eddy Inc. Mc Graw Hill Inc.

Wang, J., Huang, Y., Zhao, X. 2004. Performance and Characteristic of an Anaerobic Baffled Reactor. Bioresource Technology. 93(2). pp 205-208

Wulandari, Riswal, K., Zubair, A. 2014. Studi Identifikasi Lokasi Pembangunan IPAL Komunal dan Evaluasi IPAL Komunal yang ada di Kecamatan Panakukkang Makassar. Tugas Akhir. Universitas Hasanuddin Makassar.

Yudo, S. Indriatmoko, R.H. 2006. Evaluasi Hasil Pembangunan Instalasi Pengolah Air Limbah Domestik Tipe Komunal di Wilayah Kotamadya Jakarta Pusat. Jurnal Teknologi Lingkungan. pp 166-173. 